$$
\text { DOE|PCl90363 _. T9 }
$$

\title{
DEVELOPMENT OF ADVANCED NO $x$ CONTROL CONCEPTS FOR COAL-FIRED UTILITY BOILERS
}

DOE Contract No. DE-AC22-90PC90363

Period of Performance: September 26, 1990 to March 31, 1993

DOE/PC/90363--T9

DE93 013069

\section{Quarterly Technical Progress Report No. 7}

Period Covered by Report: April 1, 1992 to June 30, 1992

prepared by:
A. Evans
J. Newhall Pont
G. England
W.R. Seeker

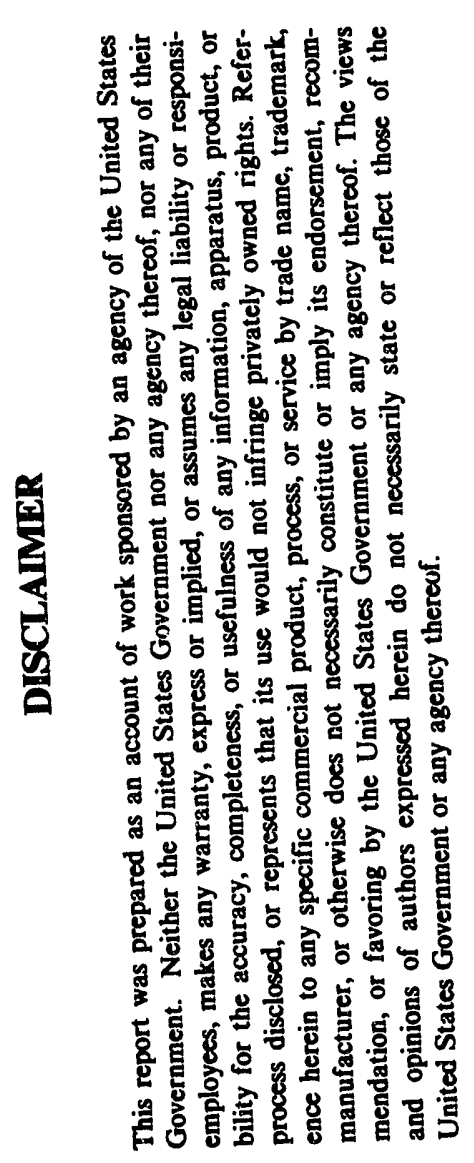

Energy and Environmental Research Corporation 18 Mason Irvine, California 92718

Date Submitted: February 11, 1993

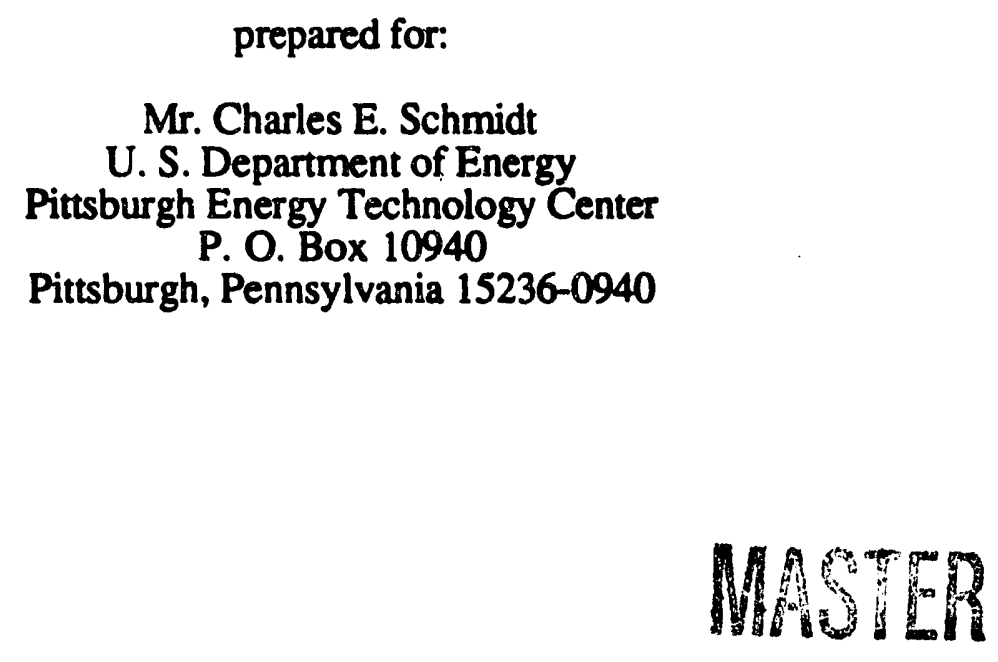




\section{Process Design \\ for \\ Reburning Tower Experiments}

\section{Performed at EER's}

Reburn Tower Experimental Combustion Facility

in August 1992 


\section{TABLE OF CONTENTS}

Secrion

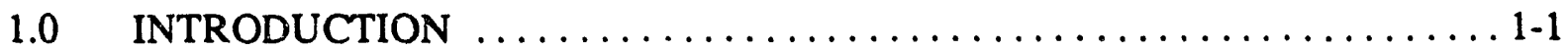

2.0 DESIGN PARAMETERS AND RESULTS $\ldots \ldots \ldots \ldots \ldots \ldots \ldots \ldots \ldots .2-1$

2.1 REBURNING INJECTION SYSTEM/ FGR $\ldots \ldots \ldots \ldots \ldots \ldots \ldots 2-1$

2.2 UREA INJECTION SYSTEM $\ldots \ldots \ldots \ldots \ldots \ldots \ldots \ldots \ldots \ldots \ldots \ldots \ldots \ldots$

2.3 BURNOUT AIR INJECTION SYSTEM $\ldots \ldots \ldots \ldots \ldots \ldots \ldots \ldots .2-9$

2.4 METHANOL INJECTION SYSTEM $\ldots \ldots \ldots \ldots \ldots \ldots \ldots \ldots \ldots, 2-10$

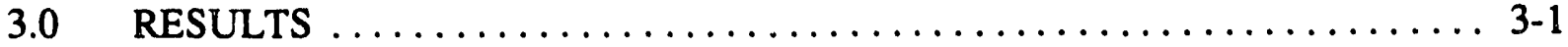

4.0 SUMMARY $\ldots \ldots \ldots \ldots \ldots \ldots \ldots \ldots \ldots \ldots \ldots \ldots \ldots \ldots \ldots \ldots, 4-1$ 


\section{LIST OF FIGURES}

Figure

Page

1-1 Application of CombiNO to $_{\mathrm{x}}$ a coal-fired utility boiler $\ldots \ldots \ldots \ldots \ldots \ldots \ldots \ldots$

1-2 EER's 10 Million Btu/hr Reburn Tower $\ldots \ldots \ldots \ldots \ldots \ldots \ldots \ldots \ldots \ldots$

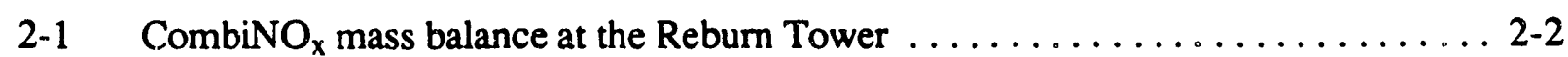

2-2 Natural gas nozzle design $\ldots \ldots \ldots \ldots \ldots \ldots \ldots \ldots \ldots \ldots \ldots \ldots \ldots . \ldots \ldots$

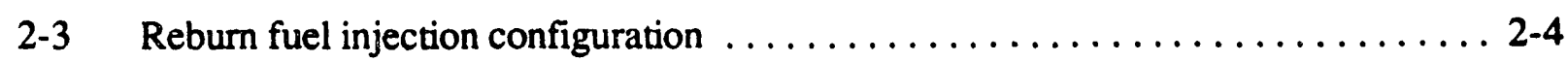

2-4 Urea lance configuration $\ldots \ldots \ldots \ldots \ldots \ldots \ldots \ldots \ldots \ldots \ldots \ldots \ldots \ldots \ldots$

2-5 Urea injection pressure chamber set-up $\ldots \ldots \ldots \ldots \ldots \ldots \ldots \ldots \ldots \ldots$

2-6 Burnout air injection configuration when injected downstream of urea $\ldots \ldots \ldots 2-10$

\section{LIST OF TABLES}

Table

Page

4-1 Process Design Summary $\ldots \ldots \ldots \ldots \ldots \ldots \ldots \ldots \ldots \ldots \ldots \ldots \ldots \ldots \ldots$ 
Hybrid technologies for the reduction of $\mathrm{NO}_{\mathbf{x}}$ emissions from coal-fired utility boilers have shown the potential to offer greater levels of $\mathrm{NO}_{\mathbf{x}}$ control than the sum of the individual technologies, leading to more cost effective emissions control strategies. Energy and Environmental Research Corporation (EER) has developed a hybrid $\mathrm{NO}_{\mathbf{x}}$ control strategy involving two proprietary concepts which has the potential to meet the U.S. Department of Energy's $\mathrm{NO}_{\mathrm{x}}$ reduction goal at a significant reduction in cost compared to existing technology. The process has been named CombiNO $_{\mathbf{x}}$.

CombiNO $_{x}$ is an integration of three technologies: modified reburning, promoted selective noncatalytic reduction (SNCR) and methanol injection. These technologies are combined to achieve high levels of $\mathrm{NO}_{x}$ emission reduction from coal-fired power plants equipped with $\mathrm{SO}_{2}$ scrubbers. The first two steps, modified reburning and promoted SNCR are linked. It has been shown that performance of the SNCR agent is dependent upon local oxidation of CO. Reburning is used to generate the optimum amount of CO to promote the SNCR agent. Approximately 10 percent reburning is required, this represents half of that required for conventional reburning. If the rebum fuel is natural gas, the combination of reburning and SNCR may result in a significant cost savings over conventional reburning. The third step, injection of methanol into the flue gas, is used to oxidize $\mathrm{NO}$ to $\mathrm{NO}_{2}$ which may subsequently be removed in a wet scrubber. Figure 1-1 illustrates how $\mathrm{CombiNO}_{\mathbf{x}}$ may be applied to a coal-fired utility boiler.

Pilot-scale tests performed at EER's $1 \mathrm{MMBtu} / \mathrm{hr}$ Boiler Simulation Facility (BSF) have demonstrated $\mathrm{NO}_{\mathrm{x}}$ reductions up to $92 \%$. The program's next phase entails process scale-up to a $10 \mathrm{MMBtu} / \mathrm{hr}$ furnace also located at EER's Santa Ana test site. This larger furnace is called the Reburn Tower and is displayed in Figure 1-2. It is a down-fired furnace consisting of 6 levels, each of which contain 14 ports for injection and sampling purposes. The furnace levels are numbered from the top down and will be referred to throughout this report.

At this point of the program, all of the CombiNO $x$ experiments have been conducted at small pilot and bench-scales. Although experiments at these scales have provided valuable insights into the controlling parameters of the CombiNO ${ }_{x}$ process, there remain questions about whether the absolute levels of $\mathrm{NO}_{x}$ reductions achieved are truly representative of what could be achieved on a 


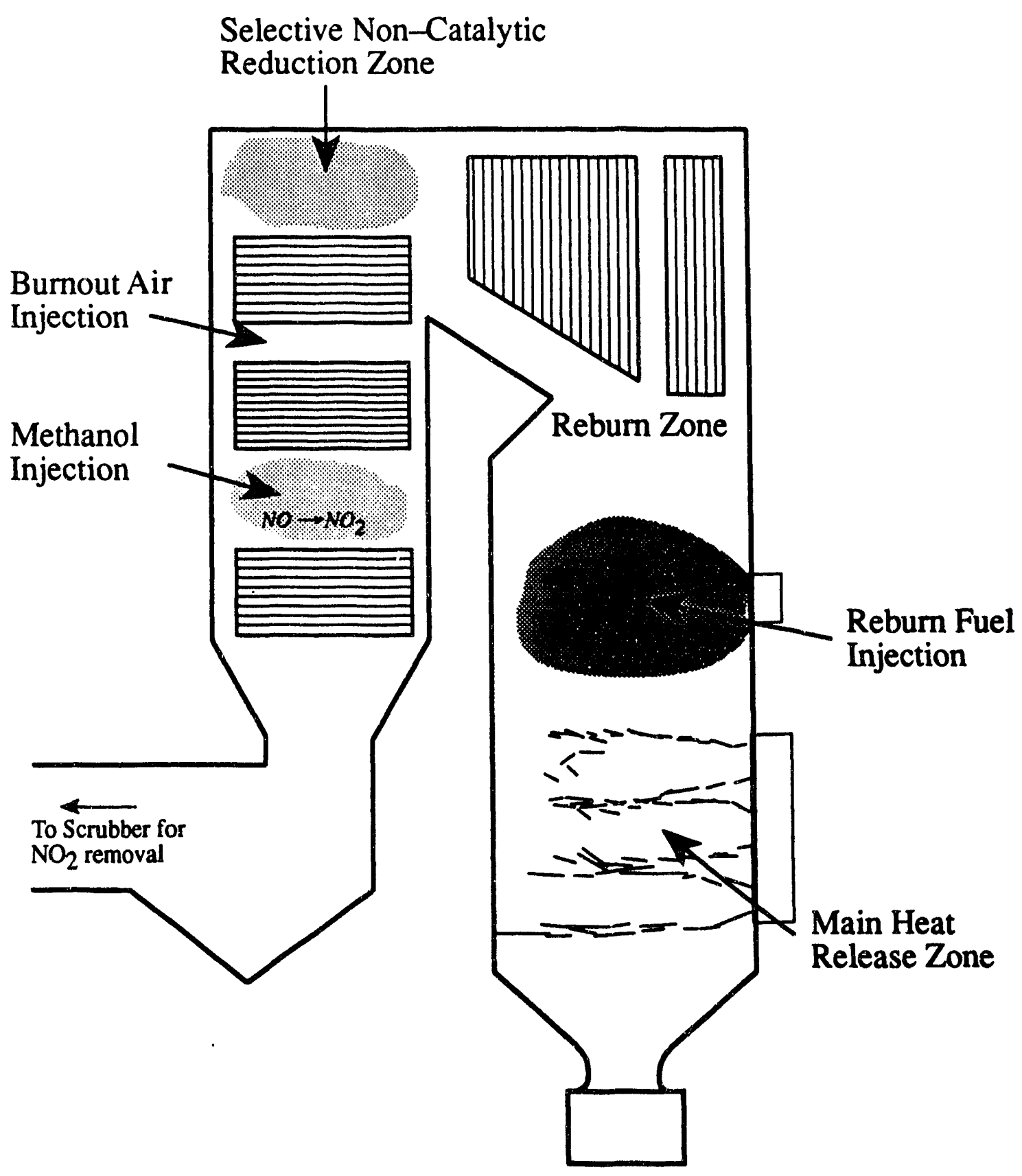

Figure 1-1. Application of CombiNOx to a coal-fired utility boiler. 


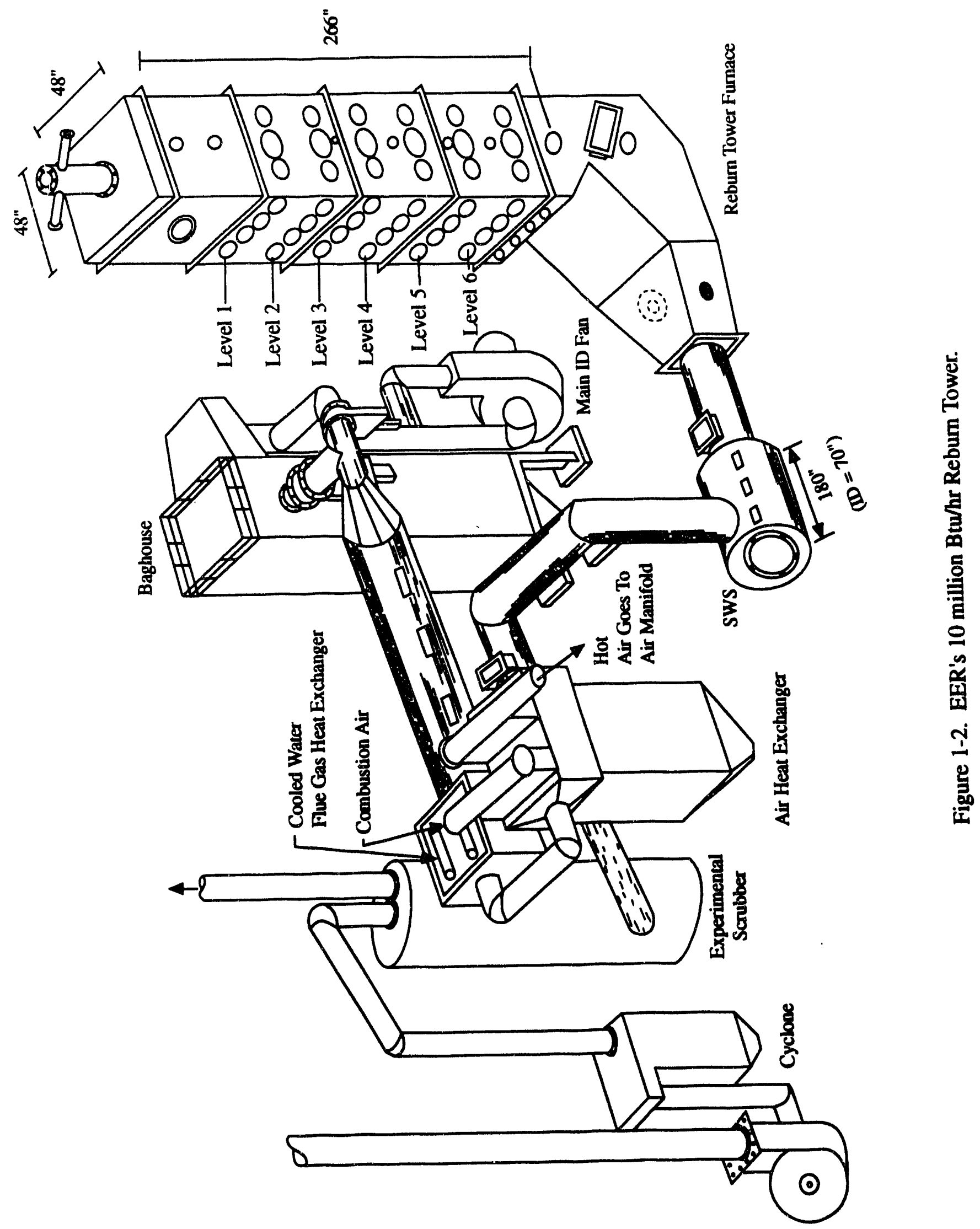


utility boiler. For example, the success of the process depends to a large extent on being able to rapidly mix the reburning fuel, urea, burnout air and methanol with the flue gas. Clearly, it is much easier to accomplish good mixing in a small furnace than in a large utility boiler.

Additionally, smaller facilities will tend to produce smaller scale mixing patterns, in particular, smaller pockets of $\mathrm{CO}$ and $\mathrm{O}_{2}$. Since the synergism between reburning and agent injection is related to $\mathrm{CO} / \mathrm{O}_{2}$ interactions, the smaller facilities do not necessarily yield $\mathrm{NO}_{\mathbf{x}}$ reductions representative of utility boilers. The Reburn Tower furnace is approximately an order of magnitude larger than the small pilot-scale facility, and the mixing characteristics are thought to be representative of full-scale boilers. Therefore, the last experimental stage of this program is to evaluate the CombiNO $\mathrm{x}_{\mathrm{x}}$ process at the Tower Furnace.

EER's experience with conventional gas reburning under the Clean Coal Technologies Program consisted of designing, installing and evaluating the reburn process at three utility boilers. In the design phase, mixing of the reburning fuel and burnout air with the flue gas was carefully evaluated. Calculations of jet trajectories and entrainment characteristics were performed, yielding a preliminary design consisting of number of jets, and size of opening, and amount of additional transport fluid required. The next step was to build a plexiglass flow model of the boiler and install the conceptual injection design. The design was modified slightly to allow for non-idealities in the boiler flue gas flow.

The CombiNO ${ }_{x}$ experiments at the Reburning Tower are intended to reflect full-scale performance. Thererore, in the design of the injection systems for the experiments, the same procedure that was used in the Clean Coal Technology process design was used with the exception of building the flow model. This document details the design of the reburning fuel, urea, burnout air and methanol injection systems used during the Reburn Tower Experiments. 
Since one of the objectives of the Reburn Tower tests is to determine how scale-up affects the CombiNO $_{x}$ process, it is desirable to achieve furnace conditions as similar to full-scale as possible. Quench rate is an important parameter which has an effect on SNCR (and methanol injection) performance. In order to obtain quench rates comparable to those of full-size boilers, water-cooled panels are inserted into the walls of the Reburn Tower, and a quench rate of $400^{\circ} \mathrm{F} / \mathrm{sec}$ can be obtained throughout the urea injection temperature range for a firing rate of $7 \mathrm{MMBtu} / \mathrm{hr}$.

The injection systems for reburn fuel, urea, burnout air, and methanol are all designed to mix quickly while achieving maximum coverage. Calculated flow rates for all injection systems are displayed in Figure 2-1, along with the flow scheme of the Reburn Tower. The following discussion describes what parameters were taken into consideration for each injection system, and how the final systems are configured.

\subsection{Rebuming Fuel Injection System / Flue Gas Recirculation (FGR)}

For Advanced Gas Reburning, only 10 percent of the total fuel input is required for fuel in the reburn zone. This results in a very low reburn fuel (natural gas) flow rate compared to the total flue gas flow rate. Therefore, to adequately mix the reburn fuel with the flue gas in the allotted amount of time (the design characteristic mixing time for the reburn fuel is $250 \mathrm{~ms}$ ), a fuel transport medium (FGR or air) is necessary. Since reburning is more efficient when less oxygen is present in the reburn zone, FGR would be a more beneficial transport medium than air. Full-scale demonstrations have also successfully utilized FGR as transport (3\% FGR was used at Hennepin Station to transport natural gas reburn fuel), for these reasons FGR is the specified transport for the Reburn Tower design.

Location of FGR extraction from the flue gas is another consideration. A location downstream of the baghouse and ID fan was chosen for two reasons. One, the baghouse would minimize ash content in the FGR, and two, the ID fan would provide positive pressure to aid in FGR transport to the furnace. Flue gas oxygen at this point of the furnace is approximately $8 \%$ (dry) by volume.

The natural gas reburn fuel injector design is shown in Figure 2-2, and injector placement is shown in Figure 2-3. This design was developed using the EER method of calculating the number of jets, 

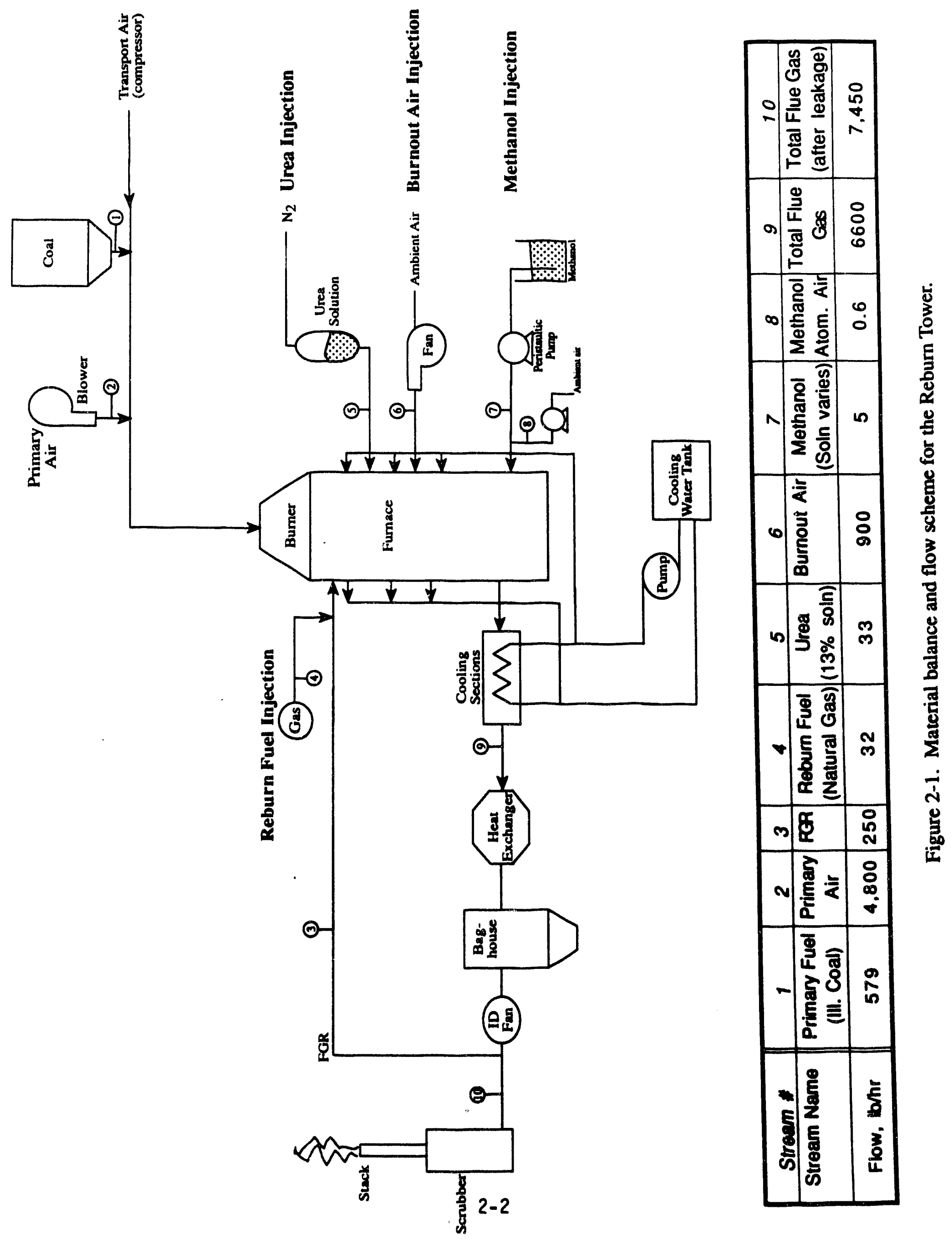

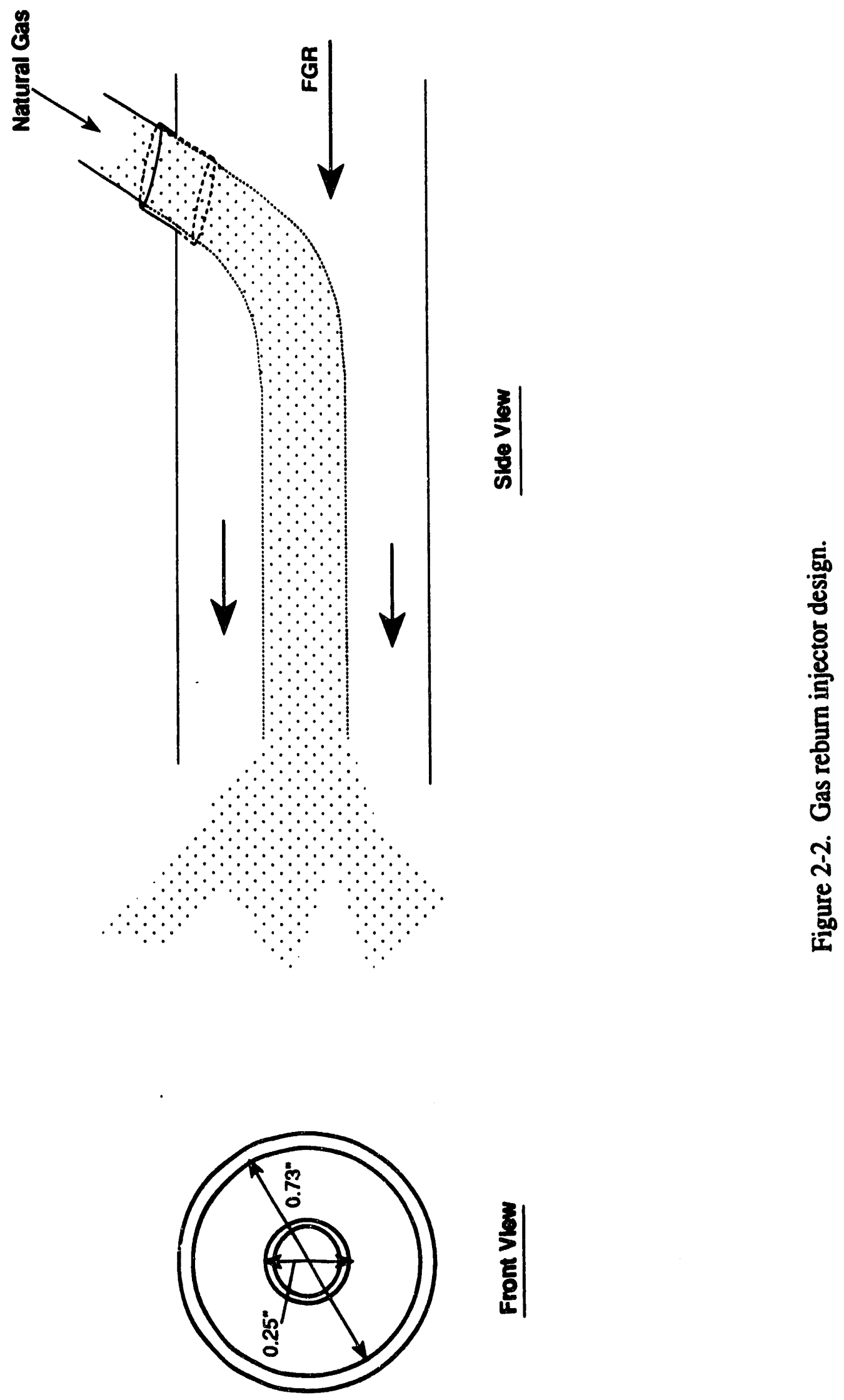

2-3 


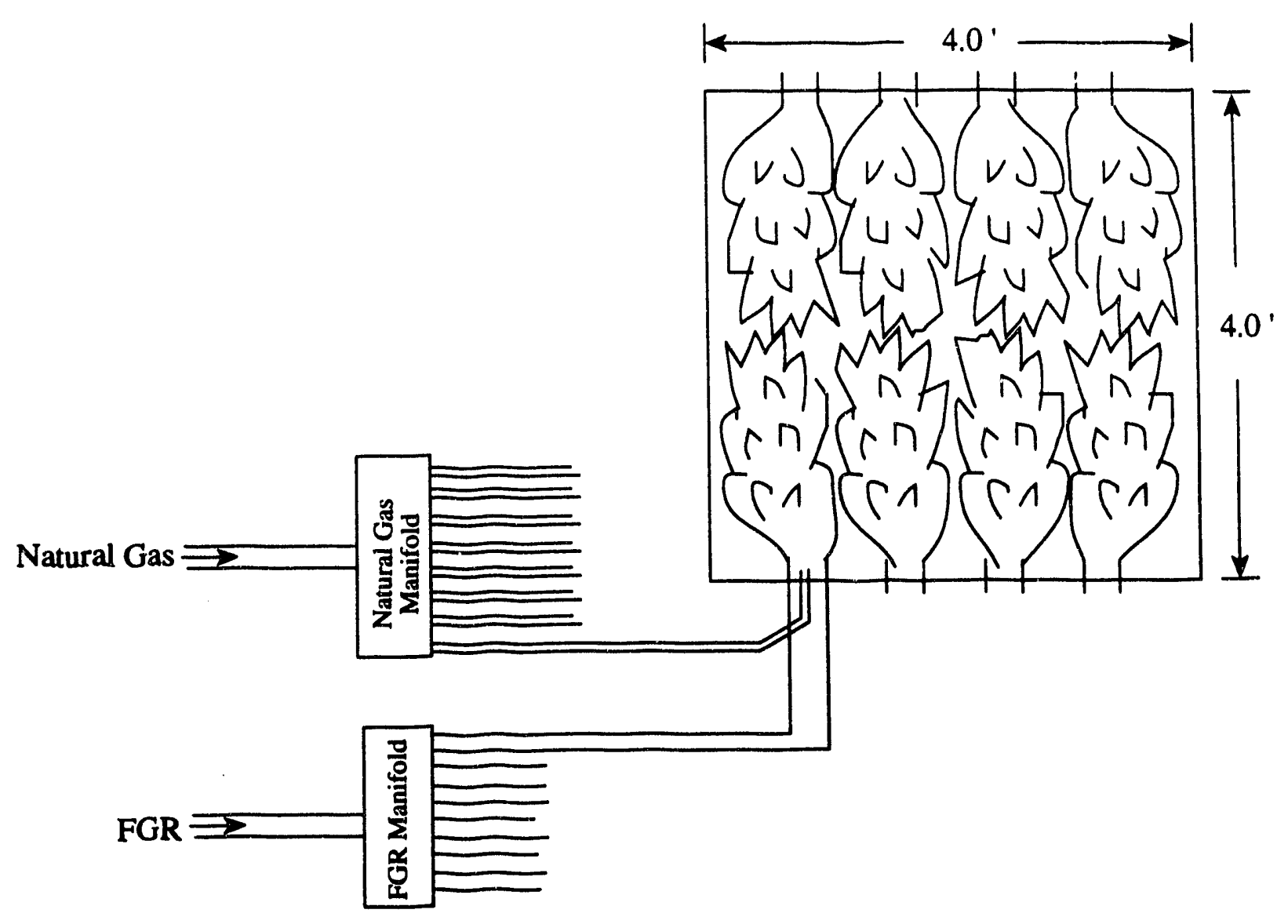

Figure 2-3. Reburn fuel injection configuration. 
jet diameter, placement and amount of transport fluid required. This method consists of evaluating the momentum flux of the jet and of the flue gas, and setting the jet diameter so that the jet has been thoroughly entrained within a set amount of time. The final design consists of 8 nozzles, four on two opposing walls, with jet velocities of approximately $7.1 \mathrm{ft} / \mathrm{sec}$. Approximately 3.4 percent FGR is required as transport. There is no tilt applied to the nozzles. The nozzles are a co-axial design with the natural gas stream in the center, and FGR around the perimeter. FGR is used to enhance the reburn fuel penetration and reduce its mixing time. The natural gas injector has an outside diameter of 0.25 inch and is encompassed by the FGR tube which has an inside diameter of 0.73 inches. For safety purposes, the FGR and natural gas are not mixed until immediately before injection in:o the furnace. Natural gas flow is set by the desired reburn and primary zone stoichiometries (referred to as $\mathbf{S R}_{1}$ and $\mathbf{S R}_{2}$, respectively). For this test series, $\mathbf{S R}_{2}$ varies between 0.99 and 1.05 while $\mathrm{SR}_{1}$ renlains constant at 1.13: this requires a maximum natural gas flow rate of $40 \mathrm{lb} / \mathrm{hr}$ and the system is designed accordingly. All reburn nozzles are located at Level 3 of the Reburn Tower.

\subsection{Urea Injection System}

The urea injection system is designed to distribute the urea solution with maximum coverage and quick mixing. The use of twin fluid nozzles was considered, but finding an adequate atomization fluid was difficult. Since the reburning zone stoichiometry must remain fuel rich, air was not considered as an atomizing fluid. FGR and steam were considered, but it was feared that high temperatures may induce crystallization of the urea, and subsequently plug the nozzles. The FGR stream could have been cooled, but this would have added significant cost to the scope of the project. Pressure atomizers require no atomization fluid and are commonly used in full-scale applications for SNCR injection. These nozzles, positioned on lances that extend across the furnace, appeared to be the most suitable design for this test series.

Sizing of the pressure atomizers is a critical factor in urea performance. Nozzle size, solution flow rate, and solution pressure all determine the size of the dispersed droplet. This droplet size is crucial because it determines how well the solution mixes with the flue gas flow. If the droplet size is too small, the drops will evaporate very close to the nozzle. This results in poor coverage, allowing flue gas to slip around the injected solution and remain untreated. If the drops are too big, they will travel downstream before they evaporate, resulting in an effective injection temperature that is lower than desired. 
In order to select the appropriate nozzle for the job, urea solution flow rate must first be determined. For the CombiNO ${ }_{x}$ tests, urea is injected at a concentration of 1.5 (moles $\mathrm{NH}$ )/ (mole of $\mathrm{NO}$ in the flue gas). By estimating initial NO concentration and flue gas flow rate, and by selecting a urea solution strength, the necessary urea solution flow rate can be determined. For the proposed test matrix conditions and urea solution strength of $13 \%$, urea solution design flow rate is $4 \mathrm{gph}$ (gallons per hour).

Using this flow rate and referring to Delevan nozzle flow requirements, a nozzle can be proposed. To assure this nozzle will achieve the necessary coverage in the Reburn Tower conditions, a droplet evaporation estimate can be made using an EER developed model. Given a droplet size (obtained from Delevan for a certain nozzle operating at a specified urea flow and pressure), flue gas velocity and temperature, and nozzle spray angle and direction, this model can estimate what percentage of the solution spray will evaporate at various radii from the nozzle center.

The final urea injection design for the Reburn Tower tests consists of ten pressure atomizers assembled on four water-cooled lances as displayed in Figure 2-4. The nozzles, manufactured by Delevan, disperse the urea solution in a $90^{\circ}$ full cone spray angle at a rate $0.4 \mathrm{gph}$ each. The nozzles recede into the water-cooled lances for protection from the heat. The lances are designed to be movable to facilitate varying the urea injection temperature/location within the furnace (between levels 4 and 6).

Instead of using a high pressure pump to feed the urea from the holding tank to the lances, a pressure chamber set-up was designed. This pressure chamber, as displayed in Figure 2-5 is filled with urea solution and pressurized with nitrogen up to $80 \mathrm{psi}$. Urea flow rate is varied by adjusting the chamber pressure. Approximate flow rates are determined through a calibration procedure in which the amount of pressure applied to the chamber is varied, and resulting flow rates are measured. Actual test flow rates can be verified by measuring a mass loss in urea solution over a given amount of time. This pressure chamber method was chosen over that of a high pressure pump due to the consistently even feed of urea solution that can be obtained. 


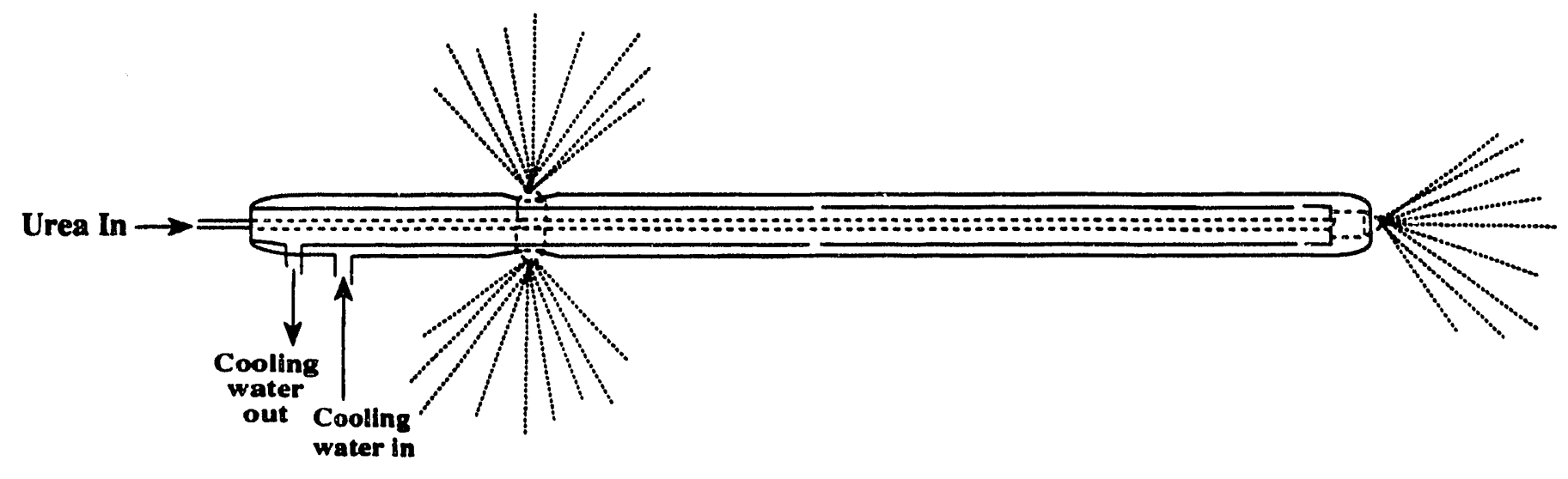

Water-cooled Lances

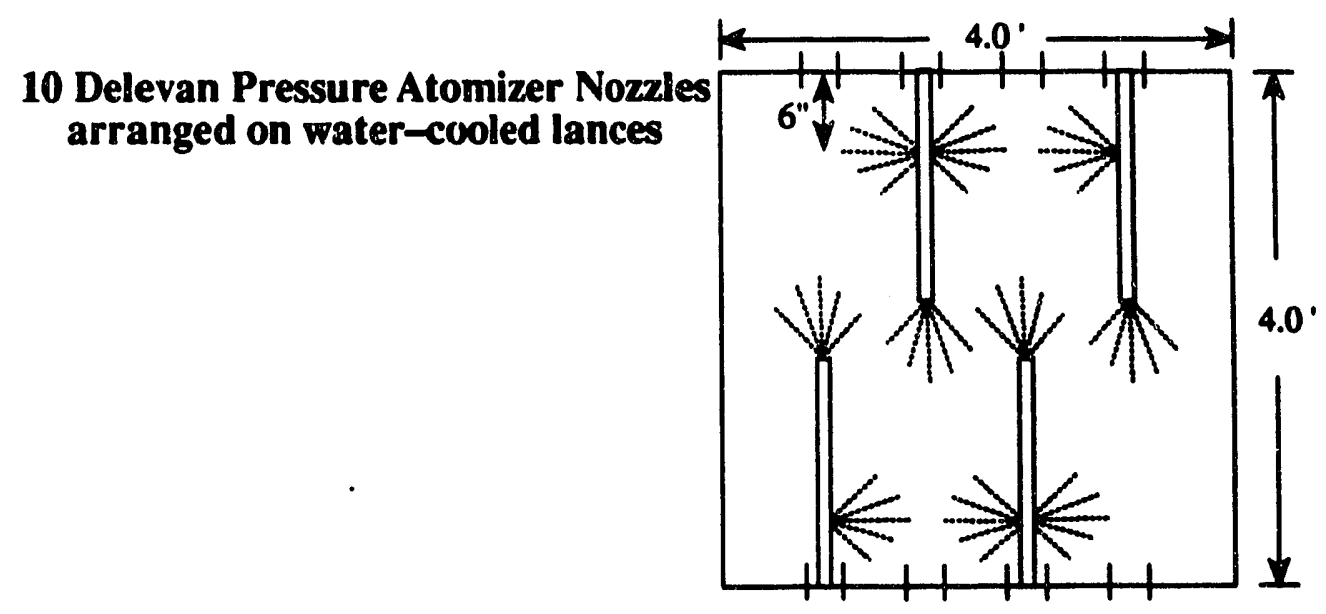

Figure 2-4. Urea lance configuration. 


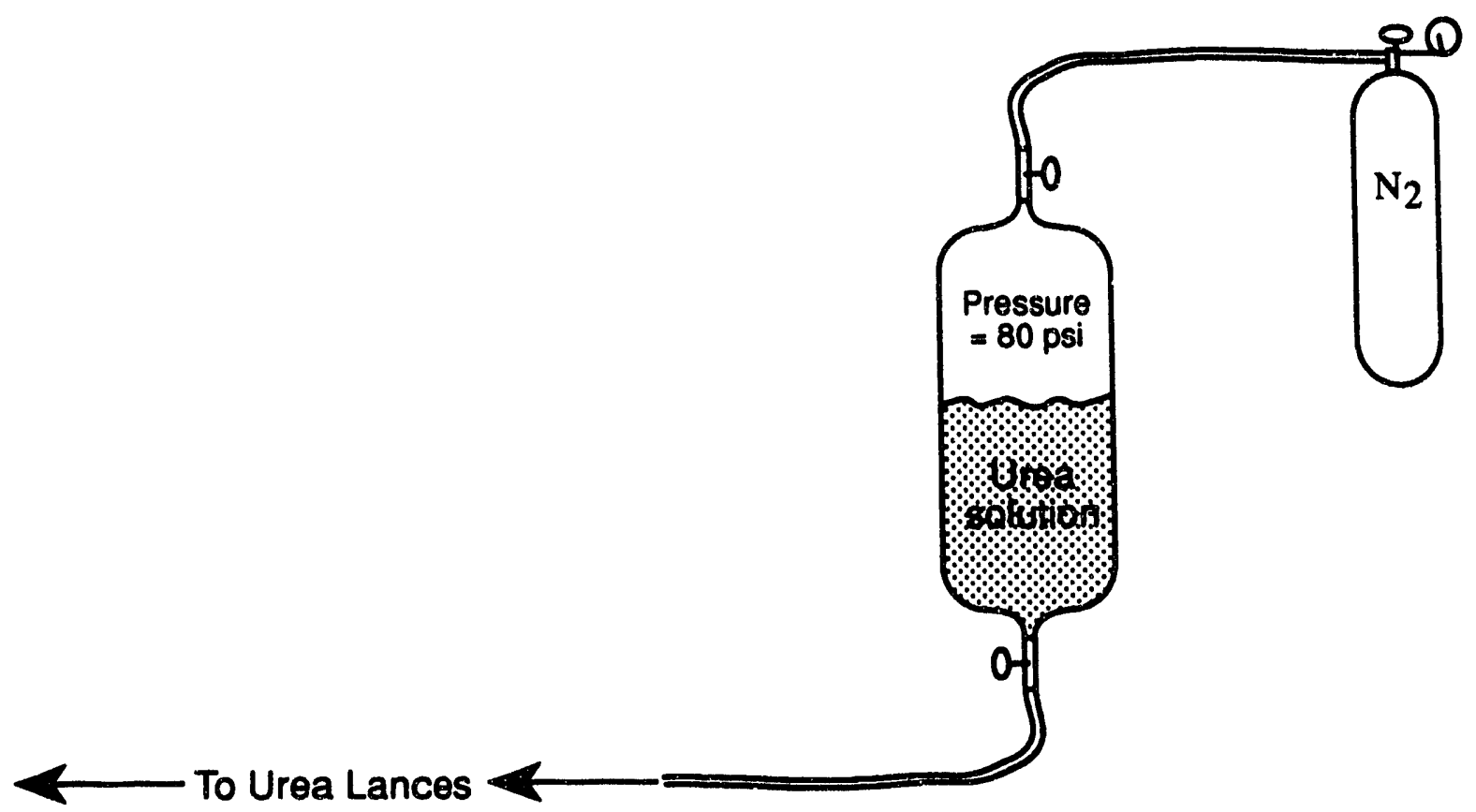

Figure 2-5. Urea injection pressure chamber. 


\subsection{Burnout Air Injection System}

To assure good coverage and penetration of the burnout air, jet configuration and size is determined in the same manner as that for FGR injection. This procedure requires knowledge of flue gas flow rates in this region, and the desired burnout air injection flow rate.

The burnout air flow rate is governed by the difference in stoichiometries between the two zones which the burnout air injection divides (refer back to Figure 1-1). The reburn zone is designed to range between stoichiometries of 0.99 and 1.10 , with the final stoichiometry after burnout air injection being 1.20 in all cases. If the reburn zone stoichiometry is very fuel rich, more burnout air will be required to bring the final stoichiometry up to 1.20 . Since the experimental test plan calls for such a large range of burnout air flow rates, two different sets of injectors were designed in order to achieve optimum penetration and entrainment for all conditions. Only one set of injectors will be used at a time.

A burnout air injection system was constructed using the EER developed method for jet design. For small amounts of burnout air addition, four 1.25 inch jets were designed with lengths of 7 inches. For larger quantities of burnout air injection, four 2.5 inch jets can be used with lengths of 15 inches. When one system is not in use it is completely removed from the furnace in order to prevent burning out unused components. A staggered configuration, as displayed in Figure 2-6, will be used for both sets of injectors.

\subsection{Methanol Injection System}

The main criteria for the methanol injection system, as for all the other systems, is to achieve rapid mixing and good coverage. Methanol is usually injected at a concentration of 1.5 times the amount of NO existing in the flue gas ( $\mathrm{MeOH} / \mathrm{NO}=1.5$, molar ratio). This concentration can be varied by changing the methanol solution strength; for the Reburn Tower tests, solution strength ranges between $40-85 \%$ by mass. A Spraying Systems, $180^{\circ}$ twin fluid nozzle was designed to inject the methanol solution at a rate of $39 \mathrm{~g} / \mathrm{min}$ with air as an atomization fluid. Droplet size for this particular nozzle has been measured to be 20 microns using a Malvern laser particle sizer. This small droplet size promotes the high flue gas contact and quick evaporation necessary for the methanol chemistry to take place at the injected temperature. The single methanol injection nozzle 


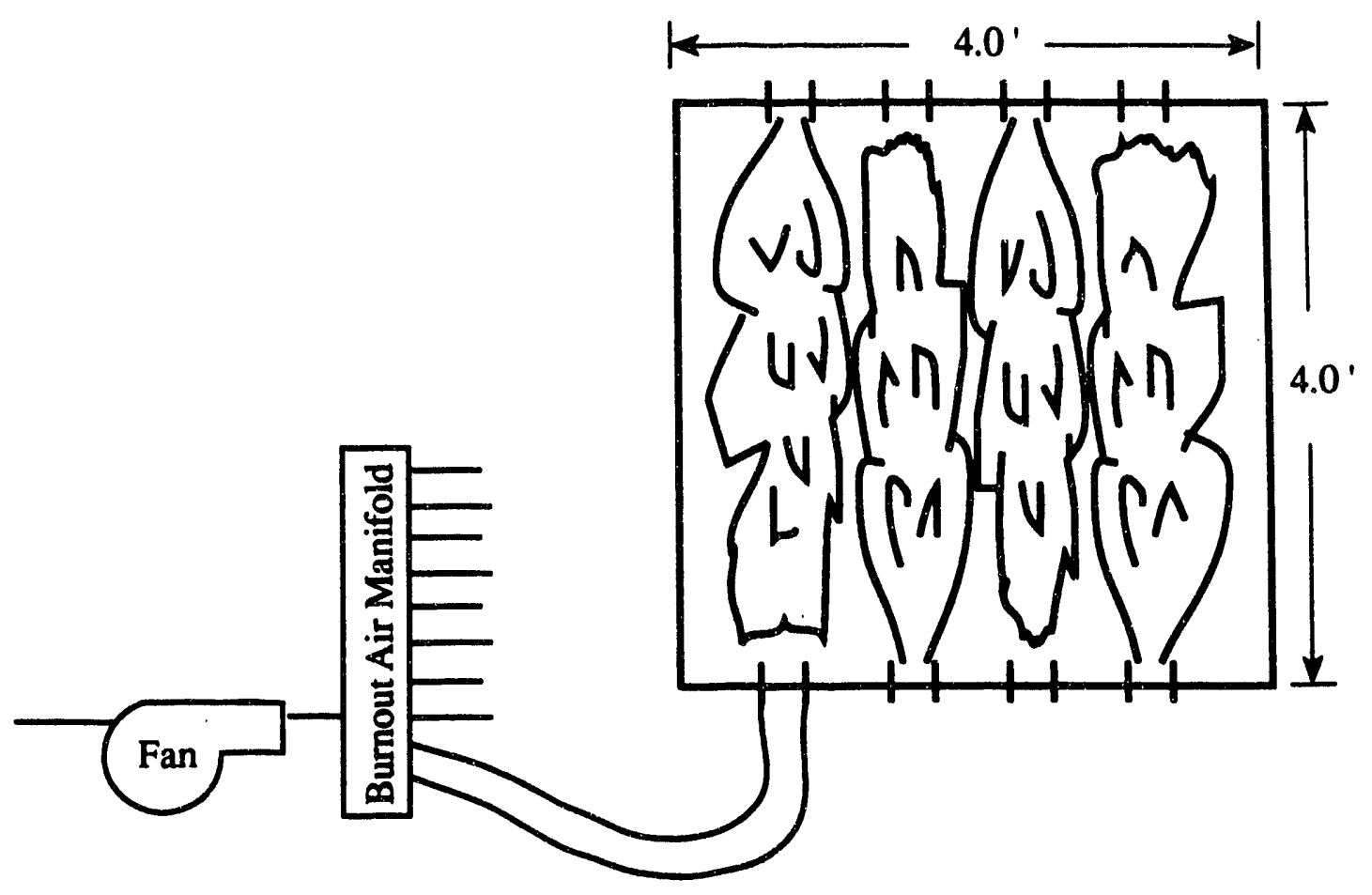

Figure 2-6. Bumout air injection configuration. 
is placed in the center of the circular duct facing up-stream to improve mixing. The aqueous methanol solution is supplied to the air stream by means of a peristaltic pump. 


\subsection{RESULTS}

The Reburn Tower tests were performed in August, 1992 using the injection systems described in this report. The following comments have been noted concerning the results of the process design:

- The reburning injection system was designed extremely well, producing $\mathrm{NO}_{\mathbf{x}}$ reductions up to $74 \%$.

- The urea injection system experienced problems with nozzles plugging. This was contributed mostly to the extremely small sizes of the nozzles. In the future, twin fluid nozzles would be recommended.

- The pressure chamber set-up for a solution feed system would not be recommended for future research testing. Preliminary calibration tests were performed so that the pressure within the urea chamber could be related to specific urea solution flow rates. When nozzles began plugging, however, calibration pressures were no longer representative of actual flow rates. Urea flows were determined only after each test point on a mass-loss basis, therefore runs were made in which the urea flow was other than that desired. This resulted in a time loss, and added confusion to the test matrix. For future tests, a high pressure pump system would be recommended so that continuous knowledge and control of the flow can be obtained.

- The burnout air injection system worked well, keeping $\mathrm{CO}$ levels within reasonable limits.

- The methanol injection system performed well.

\subsection{SUMMARY}

Table 4-1 summarizes the design parameters and the results of the process design performed for the Reburn Tower tests. 


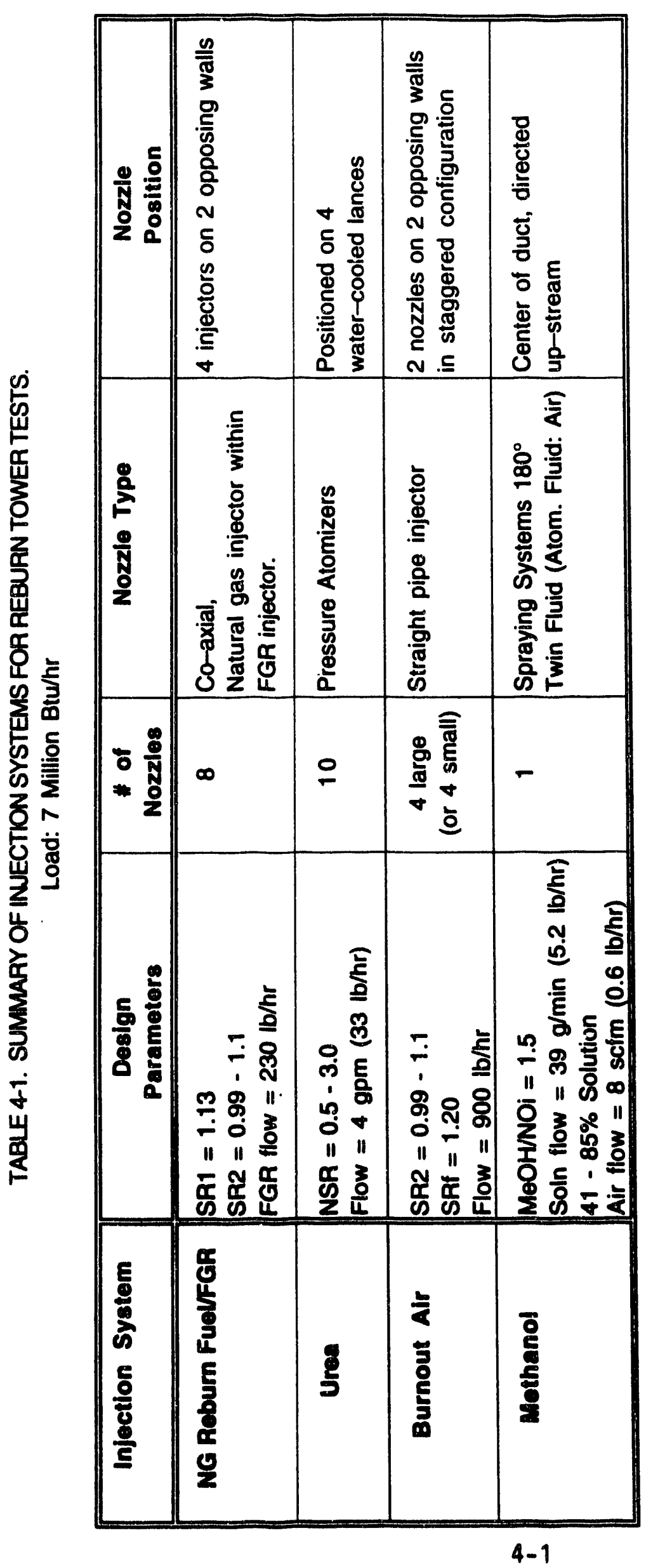



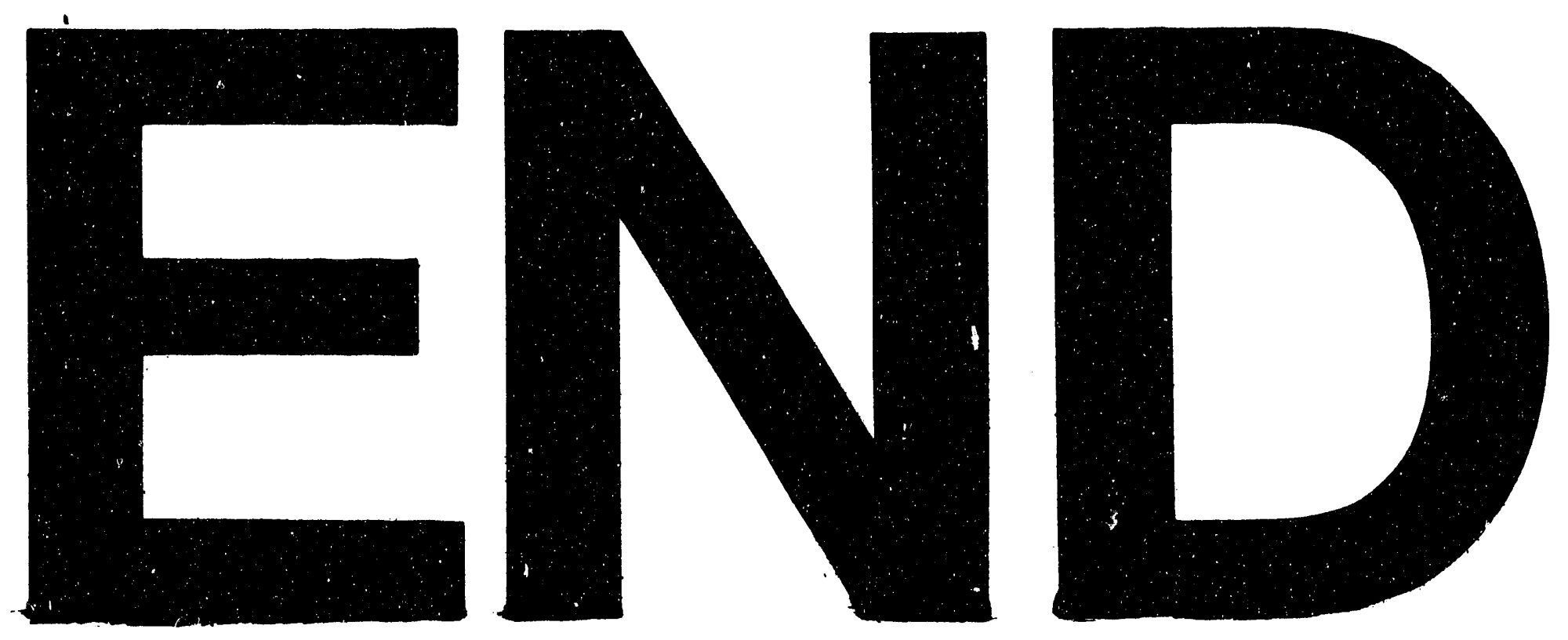

$x$

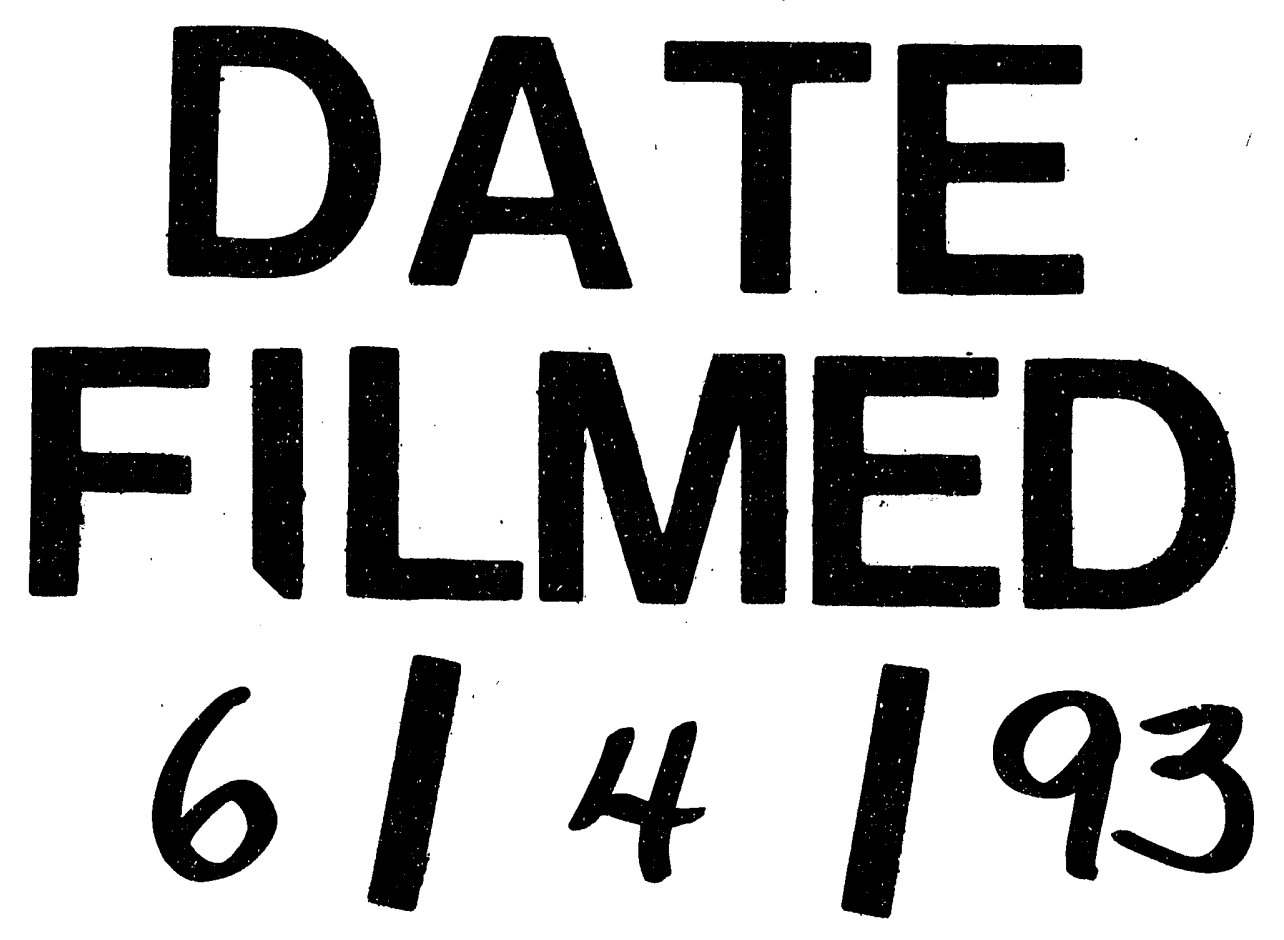


